\title{
Lake Bolsena (Central Italy): an updating study on its water chemistry
}

\author{
Rosario MOSELLO*, Silvia ARISCI and Piero BRUNI ${ }^{1)}$ \\ C.N.R. Institute of Ecosystem Study, 1. V. Tonolli 50, 28922 Verbania Pallanza, Italy \\ ${ }^{1)}$ Associazione Lago di Bolsena, Via Bixio 10, 01010, Marta (VT), Italy \\ *e-mail corresponding author: r.mosello@ise.cnr.it
}

\begin{abstract}
In spite of its importance as regards size (volume $9.210^{6} \mathrm{~m}^{3}$, max depth $151 \mathrm{~m}$ ) and as a source of drinking water, Lake Bolsena has not been studied from a hydrochemical point of view since the second half of the 60s, when a group of researchers from the Istituto Italiano di Idrobiologia co-ordinated a complete study of the limnology of the Latium lakes Bolsena, Albano, Vico, and Bracciano. In the following years analyses were performed sporadically; since the 90s, temperature and oxygen profiles and other studies were made by the Associazione Lago di Bolsena. Based on chemical profiles made in 2001-2003, this paper discusses the present chemical composition of Lake Bolsena waters, and compares them with those of other volcanic lakes in Latium (Bracciano, Albano, Nemi and Vico). The paper briefly considers the main factors influencing the water chemistry of Lake Bolsena, the variations observed from the analyses of the 60s, and the main sources of risk to water quality.
\end{abstract}

Key words: volcanic lakes, hydrochemistry, chemical processes, water renewal time

\section{INTRODUCTION}

The lake district of Central Italy (Fig. 1), with twelve lakes and a total water volume of $14.8 \mathrm{~km}^{3}$, is the second most important in Italy after that south of the Alps. The three lakes are Bolsena, Bracciano and Albano, as they comprise respectively 62,34 and $3 \%$ of the total volume of freshwater in the area, with volumes of 9.2, 5.1 and $0.5 \mathrm{~km}^{3}$ (Tab. 1; Fig. 1). Lakes Vico and Nemi are smaller $\left(0.26\right.$ and $\left.0.03 \mathrm{~km}^{3}\right)$, but are also of interest as they also occupy volcanic basins. These lakes are largely the result of Pleistocene volcanic activity (Barbanti \& Carollo 1966; Carollo \& Barbanti 1971; Camponeschi \& Lombardi 1969); the formation of lakes Bolsena and Bracciano in particular is related to subsidence and caldera formation during the final stages of volcanic activity (Pichler 1970), with direct control by large-scale tectonic processes (Nappi et al. 1991; Niessen et al. 1993). A complex volcano-tectonic origin for the lake Bolsena and Bracciano basin was suggested by Locardi et al. (1976). These two lakes are affected by young regional tectonic activity and do not represent typical caldera lakes (Niessen et al. 1993).

The importance and the potential vulnerability of these lakes is enhanced by their location in populous areas, with a great demand for water from agriculture and other civil uses; the waters of Lake Bracciano and Albano (Capelli et al. 2000) are already used for drinking supply to the city of Rome (Martini 1985).

There have been several studies of the limnology of the Latium lakes; see Margaritora (1992) for an extended review. A number of biological studies include information on their water chemistry, but this is rather scant and out of date. Most of the chemical data refer to a complete limnological study, with measurements of the main morphometric, physical, chemical and biological characteristics, carried out from the Istituto Italiano di Idrobiologia on lakes Bolsena, Bracciano and Vico between October 1965 and April 1970 (Istituto Italiano di Idrobiologia 1971; Istituto di Ricerca sulle Acque 1974). More recent chemical data were provided by Pagnotta et al. (1987), Pagnotta \& Rolle (1982), Cioni et al. (2003) and Martini et al. (1994); however, these were spot studies and did not incorporate any seasonal variation.

Lake Bolsena is the main lake in peninsular Italy as regards water volume $\left(9.2 \mathrm{~km}^{3}\right.$, Tab. 1$)$. It is located at a height of $305 \mathrm{~m}$, while its watershed has a mean height of $490 \mathrm{~m}$ and a maximum height of $690 \mathrm{~m}$ a.s.l. (Poggio Torrone), in the north-western part of the watershed. The lake has a circular shape (Fig. 2), of almost uniform width all round the lake. Its catchment has an area of $159 \mathrm{~km}^{2}$, slightly greater than the area of the lake surface $\left(114 \mathrm{~km}^{2}\right.$, Tab. 1). Lake Bolsena lies within the Vulsino volcanic district, in which the volcanic activity occurred in alternate effusive and explosive phases from five main centres of emission: Paleobolsena, Bolsena, Montefiascone, Latera and Neobolsena. The geological evolution of the district is very complex, with outcrops of a variety of rocks which are very different both from the petrographical and granulometric points of view, while massive sequences of lava flows, ignimbritic flows, layers of scoriae, lapilli and argillized tuffs can be distinguished. The fluvial and lacustrine alluvial deposits, the latter of which surround the whole perimeter of the lake, are altogether subordinate. The complex of vulcanites containing the lake has good porosity owing to the incoherent pyroclastic rocks and the fissuring of 


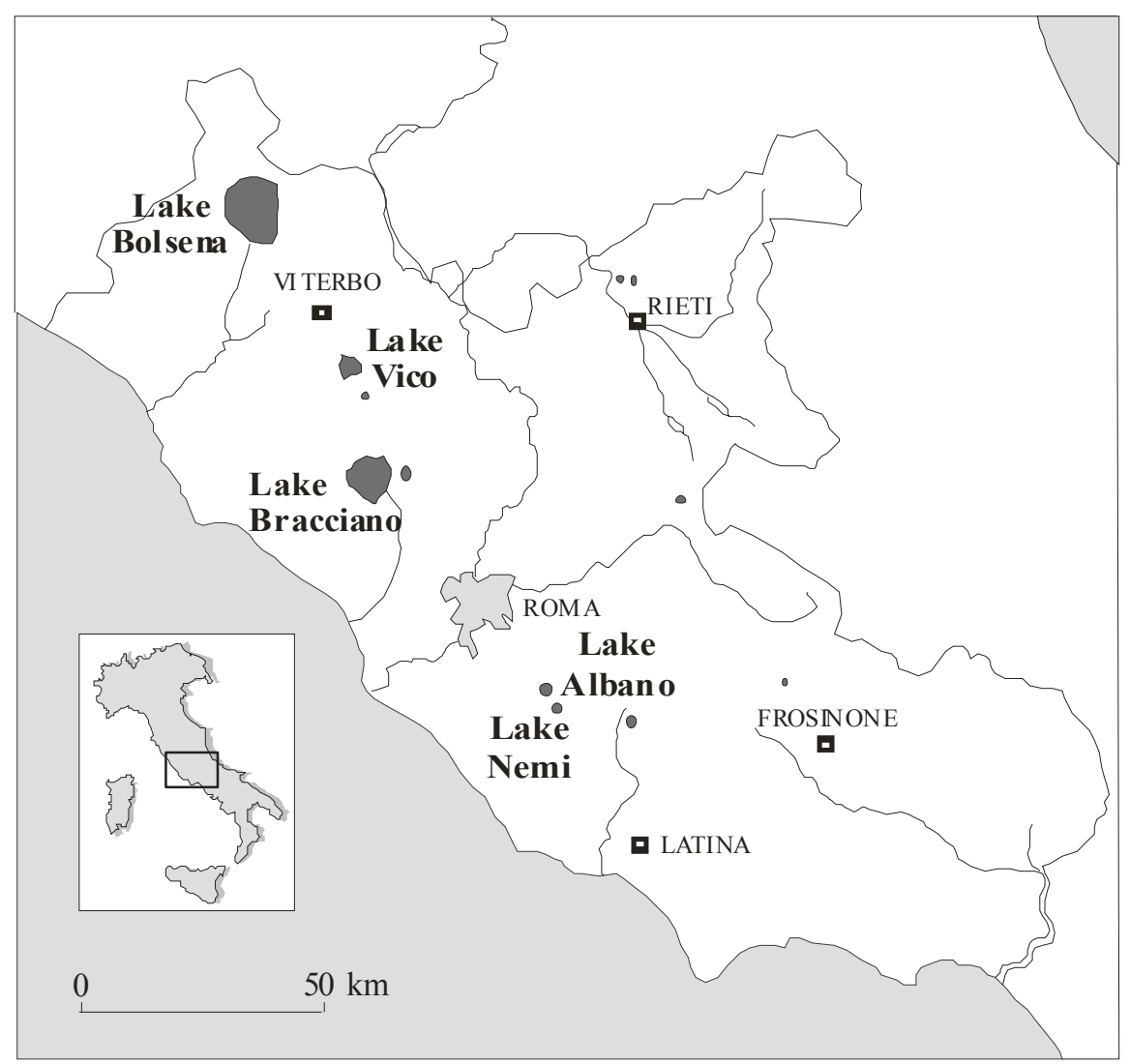

Fig. 1. Location of the main lakes in Central Italy.

Tab. 1. Main morphometric and hydrological characteristics of Lake Bolsena and other four lakes located in volcanic watershed. Watershed area not including lake surface.

\begin{tabular}{lccccccc}
\hline & $\begin{array}{c}\text { Level } \\
(\mathrm{m} \text { a.s.l. })\end{array}$ & $\begin{array}{c}\text { Watershed area } \\
\left(\mathrm{km}^{2}\right)\end{array}$ & $\begin{array}{c}\text { Lake area } \\
\left(\mathrm{km}^{2}\right)\end{array}$ & $\begin{array}{c}\text { Volune } \\
\left(10^{6} \mathrm{~m}^{3}\right)\end{array}$ & $\begin{array}{c}\text { Mean depth } \\
(\mathrm{m})\end{array}$ & $\begin{array}{c}\text { Max depth } \\
(\mathrm{m})\end{array}$ & $\begin{array}{c}\mathrm{t}_{\mathrm{w}} \\
(\text { years })\end{array}$ \\
\hline Bolsena & 305 & 159.45 & 113.6 & 9200 & 81 & 151 & 121 \\
Bracciano & 164 & 89.7 & 57 & 5050 & 88.6 & 165 & 137 \\
Albano & 293 & 16 & 6 & 464 & 77 & 175 & 48 \\
Vico & 510 & 28.05 & 12.1 & 261 & 21.6 & 48.5 & 17 \\
Nemi & 316 & 10.5 & 1.7 & 30 & 19.5 & 32.4 & 7 \\
\hline
\end{tabular}

the lava and ignimbritic flows. This gives rise to a volcanic aquifer, supported by a clayey or flyschioid sedimentary substrate, of which Lake Bolsena represents the outcropping part. The aquifer has an area of $350 \mathrm{~km}^{2}$, and thus exceeds the area of the watershed, which is 273 $\mathrm{km}^{2}$. About 22,000 people live in the watershed, increasing to 35,000 in the summer period, and the sewage reaching the lake was untreated until 1996, after which a pipeline was constructed to convey sewage from the main population centres to a treatment plant located about three $\mathrm{km}$ from the lake, along the outflow (Associazione Lago di Bolsena 2003). Further sources of pollution are the fertilisers derived from agricultural runoff. The total amount of $\mathrm{N}$ and $\mathrm{P}$ applied as fertiliser has been evaluated at 950 and $450 \mathrm{t} \mathrm{y}^{-1}$ respectively (Associazione Lago di Bolsena 2003). The hydrogeological basin is slightly larger than the lake area, bounded by an impermeable clayey layer formed of marine deposits (Pagano 1998) (Fig. 2). The Bolsena watershed is separated from the main hydrographic watershed of the River Tiber, the main river in Latium, as the lake outlet, the River Marta, drains directly into the Tyrrhenian Sea, with a total drainage basin of 1091 $\mathrm{km}^{2}$. The low ratio between total watershed surface and lake volume indicates a low theoretical water renewal time, evaluated at $120 \mathrm{y}$. However, the real turnover rate is probably greater (discussed below) making the lake more susceptible to pollution and thus demands a higher degree of care in sewage disposal and water use.

The aim of this paper is to update the information on the water chemistry of Lake Bolsena, on the basis of samplings performed from June 2000 to February 2003, comparing the results with those obtained in the sixties and seventies. Limited to the main ion composition, the 


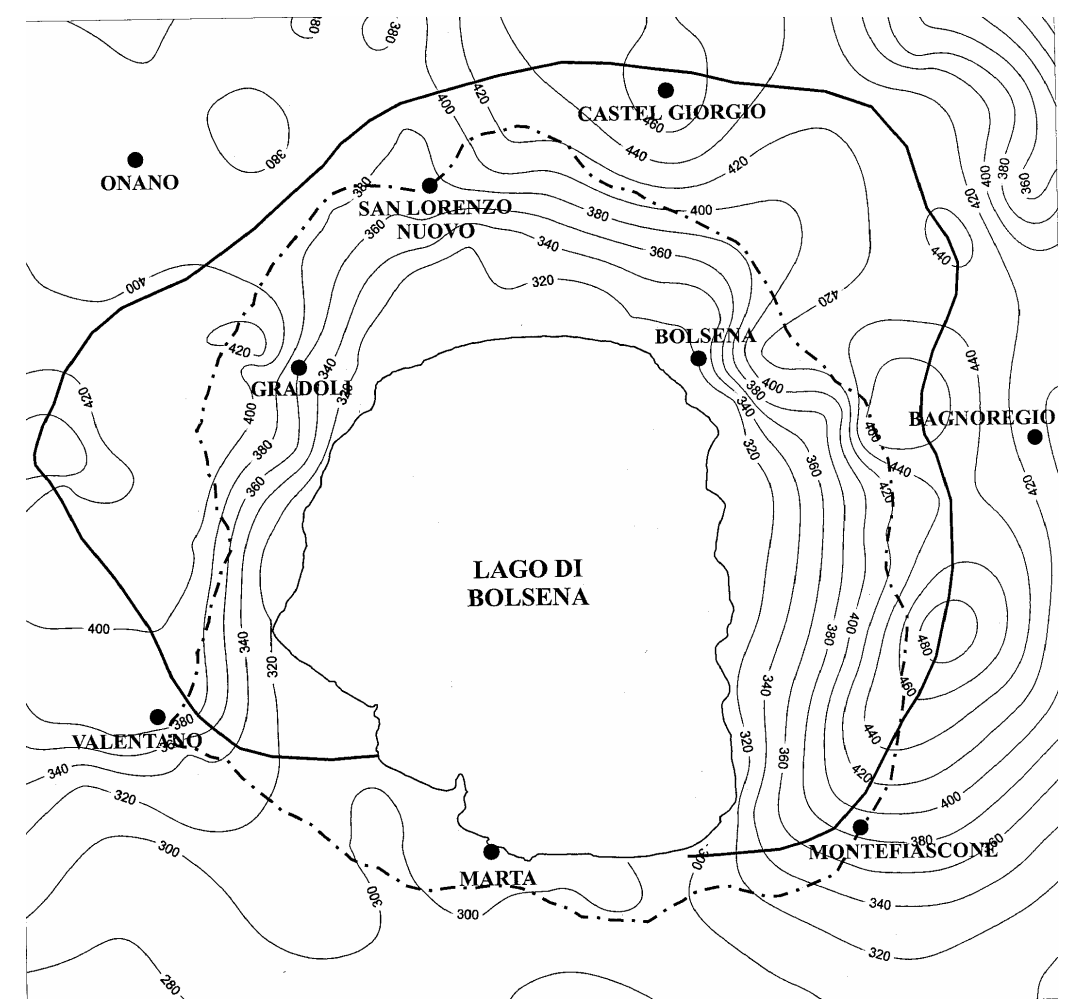

Fig. 2. Lake Bolsena, hydrographic (broken line) and hydrogeological (full line) basins.

comparison will be extended to include the other volcanic lakes of Bracciano, Albano, Nemi and Vico in Central Italy.

\section{SAMPLING AND ANALYTICAL METHODS}

Lake water samplings were performed in December 2001, April, August 2002, and February 2003 at the following depths: $0,2050,100,130 \mathrm{~m}$. Unless differently indicated, concentrations used in the text are obtained as average of the values measured at each depth weighted on the volume of the corresponding water layer.

Temperature and oxygen concentration were measured only for the April 2003 sampling, but several profiles are available for the period 1997-2000 (Associazione Lago di Bolsena 2003) and will be discussed in the paper.

Tables 2 and 3 show the chemical variables considered and the analytical methods used, the corresponding limits of detection (LOD) and repeatability at different concentrations, expressed as relative standard deviation (RSD, percent ratio between the standard deviation of 15-25 measurements and the mean value). Details of the analytical methods and the quality assurance/quality control criteria adopted in the laboratory are given by Tartari \& Mosello (1997). Metals other than the main ions were measured on the samples taken in August 2002 by ICP-AES (Simultaneous ICP-OES Vista MPX, Varian; Tab. 3) following the methodologies given by U.S. E.P.A. (1994, 1996), ISO 11885 (1996) and A.P.H.A. (1998).
Water chemistry of the lakes Albano, Mergozzo, Maggiore, Lugano, Como, Iseo and Garda, used for the comparison of the inorganic carbon equilibrium with Lake Bolsena, was obtained by analyses performed in the same laboratory with the same analytical methods.

Atmospheric deposition chemistry was measured at the forest (Quercus cerris, Turkey oak) station of Monte Rufeno, at $690 \mathrm{~m}$ a.s.l, located about $20 \mathrm{~km}$ north-east of the lake. Bulk deposition measurements, in the open and throughfall, were performed weekly, following the methods adopted in the Italian National Monitoring Programme of Forest Ecosystems (Mosello et al. 2002). The data used in the paper are the mean volumeweighted concentrations for the period January 1998December 2002. The input to the watershed was calculated using the open field bulk deposition for the lake surface $\left(113.6 \mathrm{~km}^{2}\right)$ and the throughfall deposition for the land part of the watershed $\left(159.5 \mathrm{~km}^{2}\right)$. The analytical methods used are the same as those used for the analyses of lake water.

The relationship between $\mathrm{pH}$ and bicarbonate at different atmospheric partial pressure of carbon dioxide used to discuss the inorganic carbon equilibrium of the waters is described by Stumm \& Morgan (1981). In particular, the stoichiometric approach of the equilibrium of solutes in aqueous carbonate solution has been used, having the effect of simplifying the lake Bolsena waters to a solution of calcium carbonate. The equilibrium constants of inorganic carbon and calcite solubility used, reported by the same text, are corrected for the 
Tab. 2. Analytical techniques used, lower detection limit (LOD) and repeatability at different concentrations of some of the analytes (RSD relative standard deviation).

\begin{tabular}{|c|c|c|c|c|c|c|}
\hline \multirow[t]{2}{*}{ Variable } & \multirow[t]{2}{*}{ Method } & \multirow[t]{2}{*}{ Units } & \multirow[t]{2}{*}{ LOD } & \multicolumn{2}{|c|}{ Repeatability } & \multirow[t]{2}{*}{ References } \\
\hline & & & & Mean & RDS & \\
\hline $\mathrm{pH}$ & Potentiometry & & & & & Westcott 1978 \\
\hline \multirow[t]{2}{*}{ Conductivity } & Conductometry & $\mu \mathrm{S} \mathrm{cm} \mathrm{cm}^{-1}$ & 0,5 & 14.3 & 1.4 & A.P.H.A. 1992 \\
\hline & & & & 186.1 & 0.6 & \\
\hline \multirow[t]{3}{*}{ Alkalinity } & Potentiometry & $\mu$ eq $1^{-1}$ & 1 & 37 & 5.4 & A.P.H.A. 1992, Gran 1952 \\
\hline & & & & 179 & 1.5 & \\
\hline & & & & 341 & 1.7 & \\
\hline \multirow[t]{3}{*}{ Nitrate } & Ionic chromatography & $\mu$ eq $1^{-1}$ & 1 & 14 & 3.0 & A.P.H.A. 1992, Camusso \& Polesello 2000a \\
\hline & & $\mu \mathrm{eq} 1^{-1}$ & & 38 & 1.7 & \\
\hline & & & & 104 & 0.7 & \\
\hline \multirow[t]{2}{*}{ Ammonium } & Spectrophotometry & $\mu g \mathrm{~N}^{-1}$ & 5 & 63 & 3.8 & Fresenius 1988 \\
\hline & & $\mu \mathrm{g} \mathrm{N} 1^{-1}$ & & 320 & 3.4 & \\
\hline \multirow[t]{2}{*}{ Total N } & Spectrophotometry & $\mu \mathrm{g} \mathrm{N}^{-1}$ & 100 & 540 & 5.6 & Valderrama 1981, A.P.H.A. 1992 \\
\hline & & $\mu \mathrm{g} \mathrm{N}^{-1}$ & & 1210 & 3.3 & \\
\hline \multirow[t]{3}{*}{ Reactive P } & Spectrophotometry & $\mu \mathrm{g} \mathrm{P}^{-1}$ & 3 & 8 & 12.4 & Valderrama 1977 \\
\hline & & $\mu \mathrm{g} \mathrm{P}^{-1}$ & & 165 & 5.3 & \\
\hline & & $\mu \mathrm{g} \mathrm{P}^{-1}$ & & 242 & 1.8 & \\
\hline \multirow[t]{2}{*}{ Reactive silica } & Spectrophotometry & $\mathrm{mg} \mathrm{l}^{-1}$ & 0.02 & 0.42 & 7.1 & Golterman 1978 \\
\hline & & $\mathrm{mg}^{-1}$ & & 2.61 & 1.1 & \\
\hline \multirow{2}{*}{ Sulphate } & Ionic chromatography & $\mu$ eq $1^{-1}$ & 2 & 34 & 8.2 & A.P.H.A. 1992, Camusso \& Polesello 2000a \\
\hline & & $\mu$ eq $1^{-1}$ & & 58 & 4.3 & \\
\hline \multirow[t]{2}{*}{ Chloride } & Ionic chromatography & $\mu \mathrm{eq} 1^{-1}$ & 0.5 & 6 & 10.0 & A.P.H.A. 1992, Camusso \& Polesello 2000a \\
\hline & & $\mu \mathrm{eq} 1^{-1}$ & & 9 & 6.3 & \\
\hline \multirow[t]{2}{*}{ Calcium } & Ionic chromatography & $\mu$ eq $1^{-1}$ & 0.5 & 27 & 6.3 & U.S. E.P.A. 1986, Camusso \& Polesello 2000b \\
\hline & & $\mu \mathrm{eq} 1^{-1}$ & & 74 & 3.6 & \\
\hline \multirow[t]{2}{*}{ Magnesium } & Ionic chromatography & $\mu$ eq $1^{-1}$ & 1 & 9 & 5.7 & U.S. E.P.A. 1986, Camusso \& Polesello 2000b \\
\hline & & $\mu \mathrm{eq} \mathrm{l}^{-1}$ & & 58 & 2.8 & \\
\hline \multirow[t]{2}{*}{ Sodium } & Ionic chromatography & $\mu$ eq $1^{-1}$ & 0.5 & 5 & 10.0 & U.S. E.P.A. 1986, Camusso \& Polesello 2000b \\
\hline & & $\mu \mathrm{eq} 1^{-1}$ & & 11 & 7.9 & \\
\hline \multirow[t]{2}{*}{ Potassium } & Ionic chromatography & $\mu \mathrm{eq} 1^{-1}$ & 0.2 & 3 & 13.2 & U.S. E.P.A. 1986, Camusso \& Polesello 2000b \\
\hline & & $\mu \mathrm{eq} 1^{-1}$ & & 8 & 7.7 & \\
\hline
\end{tabular}

lake temperature and water ionic strength (the extended Debye-Huckel approach, as the water ionic strength of Lake Bolsena and of the other lakes considered in the comparison have ionic strengths below $10^{-1} \mathrm{M}$ ). The presented values of carbon dioxide in atmosphere were assumed to be $355 \mu \mathrm{atm}$ (Riebesell et al. 1993).

Tab. 3. Lower detection limit (LOD), repeatability at different concentrations and Lake Bolsena measured values at the 07/08/02 sampling (units: $\mu \mathrm{g}^{-1}$ ). $\mathrm{Ag}, \mathrm{Bi}, \mathrm{Cd}, \mathrm{Co}, \mathrm{Cr}, \mathrm{In}, \mathrm{Pb}, \mathrm{Tl}, \mathrm{Mo}, \mathrm{Be}, \mathrm{Ni}, \mathrm{Ga}$ concentrations resulted lower than $1 \mu \mathrm{g}^{-1}$.

\begin{tabular}{|c|c|c|c|c|c|}
\hline \multirow[t]{2}{*}{ Variable } & \multirow[t]{2}{*}{ LOD } & \multicolumn{2}{|c|}{ Repeatability } & \multicolumn{2}{|c|}{ Measured values } \\
\hline & & Mean & RSD & $0 \mathrm{~m}$ & $130 \mathrm{~m}$ \\
\hline Aluminum & 7 & 66 & 4.2 & 9 & 9 \\
\hline Arsenic & 6 & 66 & 3.6 & $<6$ & $<6$ \\
\hline Boron & 4 & 149 & 11.1 & 390 & 395 \\
\hline Barium & 1 & 66 & 2.4 & 35 & 38 \\
\hline Copper & 2 & 33 & 3.7 & $<2$ & 4 \\
\hline Iron & 1 & 165 & 2.0 & $<1$ & 25 \\
\hline Manganese & 0.1 & 17 & 5.4 & $<0.1$ & 21 \\
\hline Selenium & 7 & 170 & 3.3 & $<7$ & $<7$ \\
\hline Zinc & 0.5 & 168 & 1.9 & $<0.5$ & 20 \\
\hline Lithium & 0.7 & - & - & 42 & 41 \\
\hline Strontium & 0.1 & - & - & 420 & 450 \\
\hline
\end{tabular}

\section{RESULTS AND DISCUSSION}

\subsection{Water chemistry}

The lake water is characterised by a high ion concentration (mean of $10.77 \mathrm{meq}^{-1}$ in the February 2003 sampling), with a prevalence of bicarbonate among the anions (38\% of the total ion concentration) and sodium among the cations (17\%) (Tab. 4). Magnesium, potassium and calcium have approximately the same concentrations, constituting 12,12 and $10 \%$ respectively of the total ion content; chloride and sulphate (8\% and $4 \%)$ are of minor importance among anions, while nitrate and ammonium are negligible, with regard to ion concentrations. The ion concentration results in a conductivity of $485 \mu \mathrm{S} \mathrm{cm}^{-1}$ at $20{ }^{\circ} \mathrm{C}$ and an ionic strength of $6.75 \mathrm{mmol} \mathrm{l}^{-1}$. $\mathrm{pH}$ values range between 8.7 and 8.1 as the mean of the epilimnion and hypolimnion, the lowest value of 7.6 being detected in the bottom waters on December 2001. The mean ion concentrations and conductivity measured in the 2001 and 2002 samplings were not significantly different, ranging between 10.5 and $10.8 \mathrm{meq} \mathrm{I}^{-1}, 475$ and $486 \mu \mathrm{S} \mathrm{cm}^{-1}$. The lowest and highest conductivity values measured at single depths (475 and $492 \mu \mathrm{S} \mathrm{cm}^{-1}$ ) were obtained respectively in the surface and bottom waters on August 2002, as an effect of thermal stratification and the biological processes going on in the thermally separated layers. The differ- 
Tab. 4. Concentrations of the main chemical variables measured in epilimnion (0-15 $\mathrm{m})$ and hypolimnion $(20-130 \mathrm{~m})$ in Lake Bolsena $\left(\chi 20{ }^{\circ} \mathrm{C}\right.$ : conductivity at $20{ }^{\circ} \mathrm{C}$; T.alk.: total alkalinity; RP, TP: reactive and total phosphorus; TN: total nitrogen; RSi: reactive silica).

\begin{tabular}{|c|c|c|c|c|c|c|c|c|c|c|c|c|c|c|c|c|}
\hline & $\begin{array}{l}\text { Depth } \\
\text { (m) }\end{array}$ & $\mathrm{pH}$ & $\begin{array}{c}\chi^{\circ} \mathrm{C} \\
\left(\mu \mathrm{S} \mathrm{cm}^{-1}\right)\end{array}$ & $\begin{array}{r}\mathrm{N}-\mathrm{NH}_{4} \\
\left(\mu \text { eq } 1^{-1}\right)\end{array}$ & $\begin{array}{c}\mathrm{Ca} \\
\left(\mu \mathrm{eq} \mathrm{l}^{-1}\right)\end{array}$ & $\begin{array}{c}\mathrm{Mg} \\
\left(\mu \text { eq } 1^{-1}\right)\end{array}$ & $\begin{array}{c}\mathrm{Na} \\
\left(\mu \text { eq } 1^{-1}\right)\end{array}$ & $\underset{\left(\mu \mathrm{eq} \mathrm{l}^{-1}\right)}{\mathrm{K}}$ & $\begin{array}{l}\text { T.Alc. } \\
\left(\mu \text { eq } 1^{-1}\right)\end{array}$ & $\begin{array}{c}\mathrm{Cl} \\
\left(\mu \text { eq } 1^{-1}\right)\end{array}$ & $\begin{array}{c}\mathrm{SO}_{4} \\
\left(\mu \mathrm{eq} \mathrm{l}^{-1}\right)\end{array}$ & $\begin{array}{l}\mathrm{N}-\mathrm{NO}_{3} \\
\left(\mu \text { eq } 1^{-1}\right)\end{array}$ & $\begin{array}{c}\mathrm{RP} \\
\left(\mu \mathrm{gl}^{-1}\right)\end{array}$ & $\begin{array}{c}\mathrm{TP} \\
\left(\mu \mathrm{g}^{-1}\right)\end{array}$ & $\begin{array}{c}\mathrm{TN} \\
\left(\mathrm{mg} \mathrm{l}^{-1}\right)\end{array}$ & $\begin{array}{c}\mathrm{RSi} \\
\left(\mathrm{mg} \mathrm{l}^{-1}\right)\end{array}$ \\
\hline \multirow[t]{5}{*}{ 07/08/2002 } & 0 & 8.73 & 475 & 0 & 878 & 1209 & 1926 & 1243 & 4007 & 838 & 406 & 1 & 2 & 7 & 0.16 & 0.02 \\
\hline & 20 & 8.46 & 484 & 1 & 993 & 1217 & 1909 & 1238 & 4098 & 823 & 398 & 1 & 4 & 13 & 0.36 & 0.14 \\
\hline & 50 & 8.15 & 486 & 1 & 993 & 1217 & 1917 & 1253 & 4095 & 826 & 406 & 8 & 1 & 10 & 043 & 0.52 \\
\hline & 100 & 8.08 & 486 & 0 & 993 & 1209 & 1904 & 1233 & 4082 & 826 & 412 & 8 & 13 & 15 & 0.39 & 0.71 \\
\hline & 130 & 7.80 & 492 & 2 & 1023 & 1209 & 1904 & 1200 & 4135 & 835 & 404 & 14 & 32 & 38 & 0.72 & 1.91 \\
\hline \multirow[t]{5}{*}{$25 / 02 / 2003$} & 0 & 8.20 & 483 & 0 & 1043 & 1283 & 1874 & 1238 & 4106 & 815 & 408 & 8 & 6 & 10 & 0.27 & 0.58 \\
\hline & 20 & 8.24 & 484 & 0 & 1043 & 1291 & 1874 & 1230 & 4105 & 818 & 396 & 8 & 7 & 13 & 0.24 & 0.57 \\
\hline & 50 & 8.23 & 485 & 0 & 1043 & 1283 & 1874 & 1230 & 4105 & 815 & 404 & 8 & 9 & 13 & 0.32 & 0.57 \\
\hline & 100 & 8.20 & 487 & 0 & 1043 & 1283 & 1878 & 1259 & 4105 & 835 & 400 & 8 & 8 & 13 & 0.30 & 0.57 \\
\hline & 130 & 8.22 & 486 & 1 & 1043 & 1291 & 1891 & 1253 & 4098 & 821 & 410 & 8 & 11 & 17 & 0.45 & 0.58 \\
\hline
\end{tabular}

ence is mostly due to calcium and alkalinity, as no relevant differences were detected in the case of the remaining main ions.

At the overturn (February 2003) nitrate was the main form of inorganic nitrogen present in the lake, with a concentration of about $110 \mu \mathrm{g} \mathrm{N}^{-1}$; ammonium shows values below $10 \mu \mathrm{g} \mathrm{N} \mathrm{I}^{-1}$, while the value of TN is about $300 \mu \mathrm{g} \mathrm{N} \mathrm{l}^{-1}$, indicating an important presence of organic nitrogen. Reactive and total phosphorus show

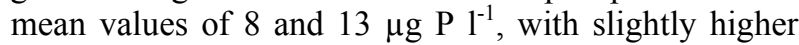
values in the deepest waters. Reactive silica concentration was $0.57 \mathrm{mg} \mathrm{Si}^{-1}$. Compared to water during the overturn, the nutrient elements were depleted during thermal stratification due to increased primary production and sedimentation. When overturn occurred the nutrient levels in the upper waters were replenished by mixing with the nutrient replete deeper waters. Peak values of 32 and $38 \mu \mathrm{g} \mathrm{P}^{-1}$ for reactive and total phosphorus were measured at $130 \mathrm{~m}$ in August 2002. These values, considered together with those of ammonium (30 $\left.\mu \mathrm{g} \mathrm{N}^{-1}\right)$ and nitrate $\left(190 \mu \mathrm{g} \mathrm{N}^{-1}\right)$, do not indicate, on this date, a situation of marked oxygen depletion or anoxia. Measurements of other chemical variables made in summer 2002 (Tab. 3) show low concentrations of strontium (420 and $450 \mu \mathrm{g} \mathrm{l}^{-1}$ at 0 and $130 \mathrm{~m}$, respectively), lithium (42 and $41 \mu \mathrm{g} \mathrm{l}^{-1}$ ) and barium (35 and 38 $\mu \mathrm{g} \mathrm{l}^{-1}$ ), while iron and manganese, below the LOD at the surface, increase to 25 and $21 \mu \mathrm{g} \mathrm{l}^{-1}$ in the hypolimnion; values for several other trace metals are below the LOD (Tab. 3). The values of boron (390-395 $\mu \mathrm{g} \mathrm{l}^{-1}$ ) are of interest as they are high compared with those of natural waters in the absence of urban pollution (Tartari \& Camusso 1988). Boron is frequently present in hydrothermal waters as a result of volcanic activity (Arnorsson \& Andresdottir 1995); values up to milligrams per litre were measured in a series of volcanic springs in the area of the volcano Etna (Parello et al. 2001).

\subsection{Processes affecting lake water chemistry}

Weathering in the watershed is considered the primary process regulating the concentrations of alkalinity, calcium, magnesium, sodium and potassium. This con- clusion is supported by the close similarities between the ion balance of Lake Bolsena and those of the other four lakes (Bracciano, Albano, Vico, Nemi) located in watersheds with the same geo-lithology (Fig. 3). Ion concentrations, from the highest to the lowest, occurred in the following order:

$$
\mathrm{HCO}_{3}>\mathrm{Na}>\mathrm{Ca}, \mathrm{Mg}, \mathrm{K}>\mathrm{Cl}>\mathrm{SO}_{4}>\mathrm{NO}_{3}
$$

By way of comparison, the ion composition of the lakes in the southern Alpine district, including the major Italian lakes Garda, Maggiore, Como and Iseo (Manca et al. 1992), is as follows:

$$
\mathrm{Ca}, \mathrm{HCO}_{3}>\mathrm{SO}_{4}, \mathrm{Mg}>\mathrm{Na}, \mathrm{K}, \mathrm{NO}_{3}, \mathrm{Cl}
$$

Bicarbonate concentrations are the main ion species contributing to total alkalinity (TA), as evaluated from the inorganic carbon speciation, taking into account temperature and ionic strength (e.g. Stumm \& Morgan 1981). At the highest $\mathrm{pH}$ value of 8.7 , measured in the epilimnion in August 2002 (Tab. 4), the percentage of $\mathrm{H}_{2} \mathrm{CO}_{3} *$ (carbonic acid and hydrated carbon dioxide), $\mathrm{HCO}_{3}{ }^{-}$and $\mathrm{CO}_{3}{ }^{2}$ was $0,98,2 \%$ of the total inorganic carbon concentration $\left(4.0 \mathrm{mmol} \mathrm{l}^{-1}\right)$; at the lowest $\mathrm{pH}$ of 7.6 values were $6,94,0 \%$ of the CT concentration $(4.3$ mmol l-1).

A second process contributing to lake water chemistry is the contribution of atmospheric deposition of ions to the watershed and lake surface. This was evaluated using the data collected in the permanent forest plot of Monte Rufeno (Fig. 1) about $20 \mathrm{~km}$ north-east of the lake. The effect on the lake concentrations of the atmospheric input of ions (Tab. 5) was evaluated assuming the ions behaved conservatively (i.e. no exchange of mass between water and sediments) at steady state conditions (Vollenweider 1975):

$$
\left[\mathrm{m}_{\mathrm{w}}\right]=\mathrm{I}_{\mathrm{m}} / \mathrm{r}_{\mathrm{w}}
$$

where $\left[\mathrm{m}_{\mathrm{w}}\right]$ is the concentration of the solute $\mathrm{m}$ in water $\left(\right.$ eq $\left.\mathrm{m}^{-3}\right), \mathrm{Im}$ is the load of the solute $\mathrm{m}$ divided by the lake volume (eq $\left.\mathrm{m}^{-3} \mathrm{y}^{-1}\right), \mathrm{r}_{\mathrm{w}}$ is the flushing coefficient $\left(\mathrm{y}^{-1}\right)$. The ratio between calculated and measured concentrations gives a rough estimation the potential 


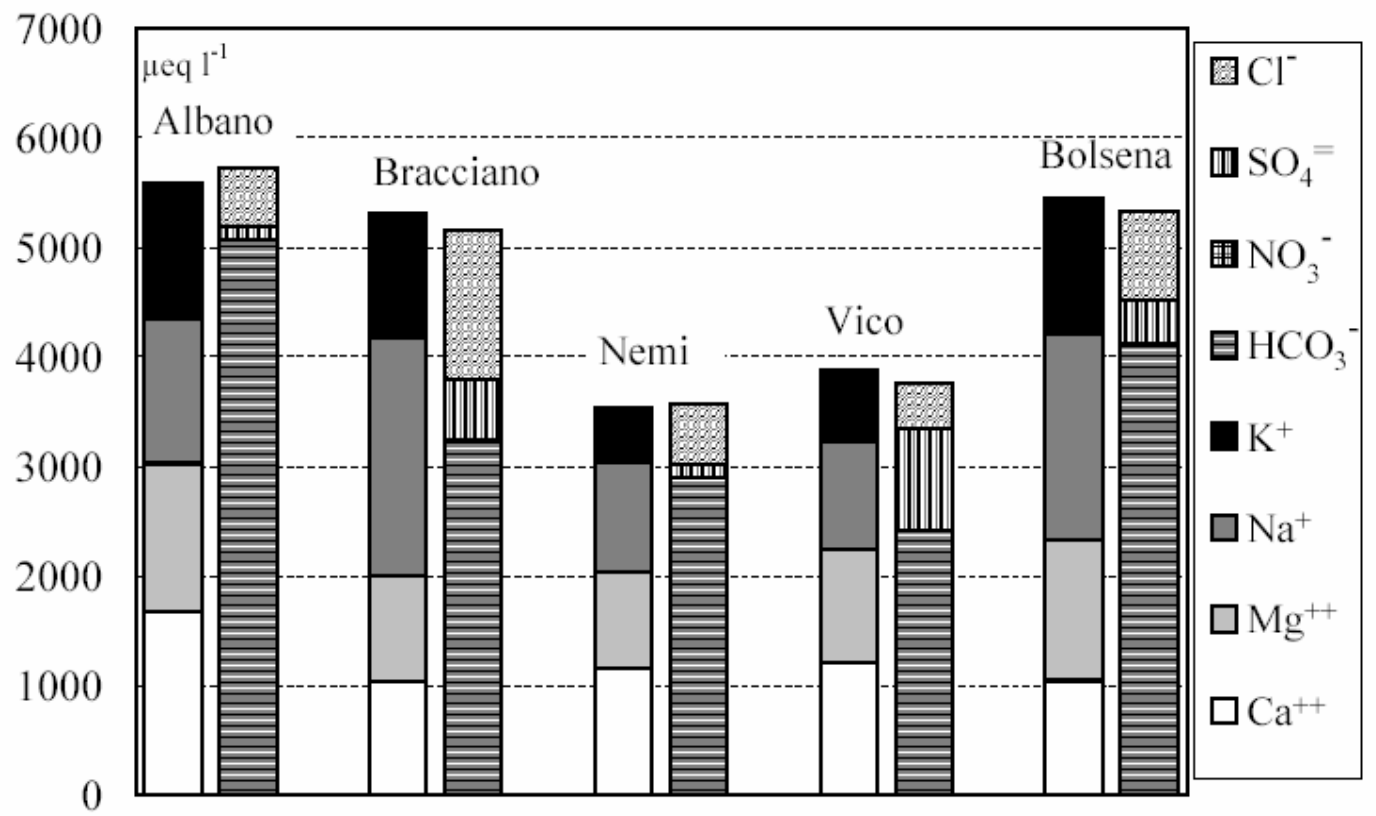

Fig. 3. Ion balance of five lakes located in volcanic watersheds.

Tab. 5. Mean (1998-2002) atmospheric load of ions to Lake Bolsena, in-lake calculated ion concentration in relation to water flushing rate and of in lake measured concentrations.

\begin{tabular}{|c|c|c|c|c|c|c|c|c|c|c|c|}
\hline & Units & $\mathrm{H}$ & $\mathrm{NH}_{4}$ & $\mathrm{Ca}$ & $\mathrm{Mg}$ & $\mathrm{Na}$ & $\mathrm{K}$ & $\mathrm{TA}$ & $\mathrm{SO}_{4}$ & $\mathrm{NO}_{3}$ & $\mathrm{Cl}$ \\
\hline bulk open field & meq $\mathrm{m}^{-3} \mathrm{y}^{-1}$ & 4 & 20 & 77 & 21 & 67 & 7 & 39 & 46 & 30 & 73 \\
\hline throughfall & meq $\mathrm{m}^{-3} \mathrm{y}^{-1}$ & 3 & 16 & 85 & 41 & 99 & 43 & 47 & 53 & 39 & 113 \\
\hline load to the watershed & meq $\mathrm{m}^{-3} \mathrm{y}^{-1}$ & 4 & 18 & 81 & 33 & 86 & 28 & 44 & 50 & 35 & 96 \\
\hline lake calculated conc. & meq $\mathrm{m}^{-3}$ & 0.02 & 0.11 & 0.49 & 0.20 & 0.52 & 0.17 & 0.27 & 0.30 & 0.21 & 0.58 \\
\hline lake measured conc. & meq $\mathrm{m}^{-3}$ & 0.00 & 0.01 & 1.04 & 1.29 & 1.88 & 1.24 & 4.10 & 0.40 & 0.01 & 0.82 \\
\hline calculated/measured & - & - & 10.75 & 0.47 & 0.16 & 0.28 & 0.14 & 0.06 & 0.75 & 26.76 & 0.71 \\
\hline
\end{tabular}

role of atmospheric deposition in contributing to the inlake concentrations. The ratio is relatively high in the case of sulphate and chloride $(0.75$ and 0.71 respectively); it is lower, but still significantly high in the case of calcium (values). The highest ratio for nitrogen compounds (value) indicates that atmospheric deposition is also an important source of this element. On the other hand it must be said that nitrogen is not a 'conservative' element, in the watershed, it is taken up during vegetative growth, in lake water it can be metabolised by phytoplankton and segregated in the sediments or released to the atmosphere by denitrification processes (Rabalais 2002). The remaining ions show lower, less significant values indicating a main role of weathering processes in determining lake concentrations.

Biological processes are important in determining seasonal variations of chemical compounds in lake waters (García-Ruiz et al. 2000). Previous studies show lower nitrate, silica, reactive and total phosphorus concentrations in the epilimnion in summer compared to the values at the overturn (Istituto Italiano di Idrobiologia 1971). The settling of autochthonous and allochthonous organic material and their subsequent breakdown results in higher nitrate, total nitrogen, and silicate concentrations in the hypolimnion, as well as oxygen depletion which resulted in anoxic conditions below a depth of $120 \mathrm{~m}$ in the late autumn.

A further result of primary production is the formation of calcite in the epilimnion. This is a result of carbon dioxide uptake and an increase in $\mathrm{pH}$, which results in higher concentrations of carbonate and so reaching calcite saturation (Koschel 1997). The calcite values of August 2002 sampling show an oversaturation of the upper $20 \mathrm{~m}$ of water, with ratios between ion activity product and calcite saturation ranging from 8 (surface) to $3(20 \mathrm{~m})$. Calcite oversaturation is a frequent condition of lake waters in summer, but does not necessarily lead to calcite precipitation: phytoplankton typology, mainly the presence of nanoplankton and picoplankton, seems to be fundamental in calcite precipitation (Kurtz 2000; Hartley et al. 1995; Thompson et al. 1997). In Lake Bolsena, calcium and alkalinity values measured in August 2002, compared with those at the overturn (Tab. 4), do not exclude the formation of calcite in the epilimnion, although it is likely that a portion of the set- 


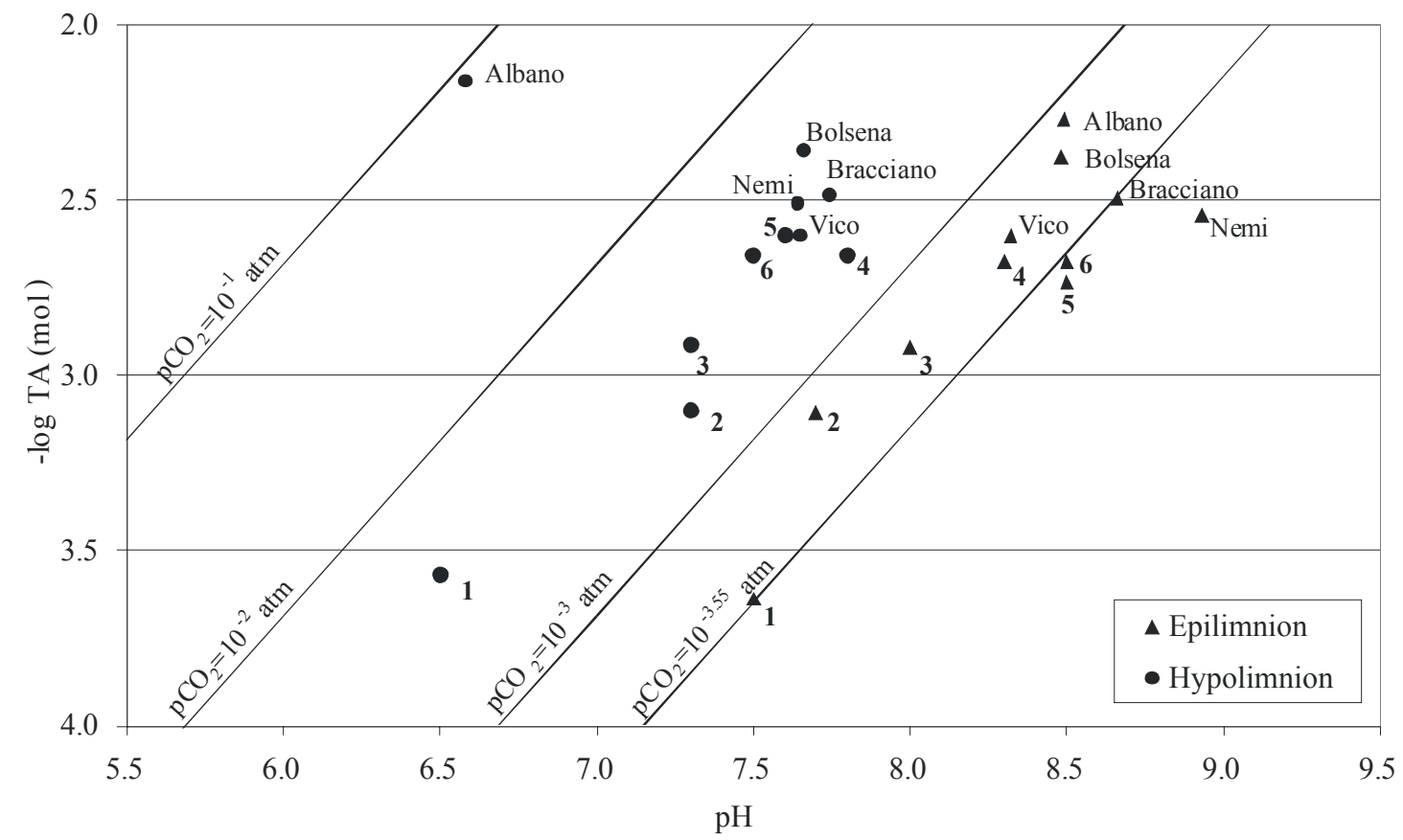

Fig. 4. Relationship between $\mathrm{pH}$ and total alkalinity in water of the surface and deep waters of the five Latium lakes compared with those of deep southern alpine lakes Mergozzo (1), Maggiore (2), Como (3), Garda (4), Lugano (5) and Iseo (6) at the summer stratification. The lines indicate the equilibrium values for the dissolution of calcite at different values of partial pressure of $\mathrm{CO}_{2}$ (atm).

tling crystals is re-dissolved in the deeper waters due to higher carbon dioxide concentrations. In some volcanic lakes, which accumulate gases rich in $\mathrm{CO}_{2}$ and other carbon components, such as $\mathrm{CH}_{4}$, can reach such high levels of oversaturation as to produce catastrophic gas exsolution, as occurred in the Cameroon lakes Nyos and Monoun (Sigurdsson et al. 1987, Giggenbach 1990). Here, evidence seem to suggest that the higher $\mathrm{CO}_{2}$ concentration in the deep waters of Lake Bolsena appears to be the result of organic matter degradation rather than volcanic activity. The absence of $\mathrm{CO}_{2}$ oversaturation is highlighted by the relationship between $\mathrm{pH}$ and TA (Fig. 4) in the surface and deep waters of the five lakes considered, compared with the deep lakes of the southern slope of alpine area. On the other hand, $\mathrm{CO}_{2}$ oversaturation is present in the deep waters of Lake Albano (Martini 1994; Cioni 2003). The source of this $\mathrm{CO}_{2}$ has been attributed external fluids entering the lake derived from magmatic activity, deciphered using the ratio ${ }^{3} \mathrm{He} /{ }^{4} \mathrm{He}$ (Funiciello et al. 2002). This could also explain the low $\mathrm{pH}$ value of the hypolimnic waters of Lake Albano, in comparison with those of other deep lakes (Fig. 4), even though, fortunately, the values are not so high as to cause alarm (Cioni et al. 2003).

Other important processes affecting the seasonal variations of water chemistry are the development and the breakdown of thermal stratification which has major implications on the biological modification of the lake water. Temperature and oxygen profiles available for Lake Bolsena in the study of the early 60 s and since the 90s (Fig. 5) show that Lake Bolsena is monomictic, reaching the overturn in January/February. Thermal stratification starts in April and ends in December, with the highest epilimnion temperatures $\left(24-26^{\circ} \mathrm{C}\right)$ reached in July/ August. Profiles show that there is marked oxygen depletion in the water layer below $50 \mathrm{~m}$ and a condition of anoxia at the end of the autumn, confined to the water layers below $110 \mathrm{~m}$.

\subsection{Long term evolution of water chemistry, hydrology and temperature}

The comparison of these results with those obtained in the period 1966-1970 (Gerletti 1967; Istituto Italiano di Idrobiologia 1971) does not highlight any major differences in the ionic balance (Fig. 6), in spite of the different analytical techniques used. On the other hand, reactive $\mathrm{P}$ concentrations at the end of thermal stratification (Tab. 4) are slightly higher than those measured in the $60 \mathrm{~s}$; a marked oxygen deficit was also detected in this part of the season, with anoxia in the deepest water, combined with higher concentrations of ammonium. The data collected in this study indicates that the lake is mesotrophic with a slight increase in trophic level compared to that found in the previous study. This increase is also confirmed by palaeolimnological studies, which pointed out higher algal pigment and biogenic silica in the upper sediments (Masaferro 1994; Lami et al. 1994). On the other hand, marked variations were observed in the winter temperature of the lake water, from 1969 to 1998 , there was a mean increase in the water temperature from 7.4 to $8.4{ }^{\circ} \mathrm{C}$ (Ambrosetti et al. 2003). 

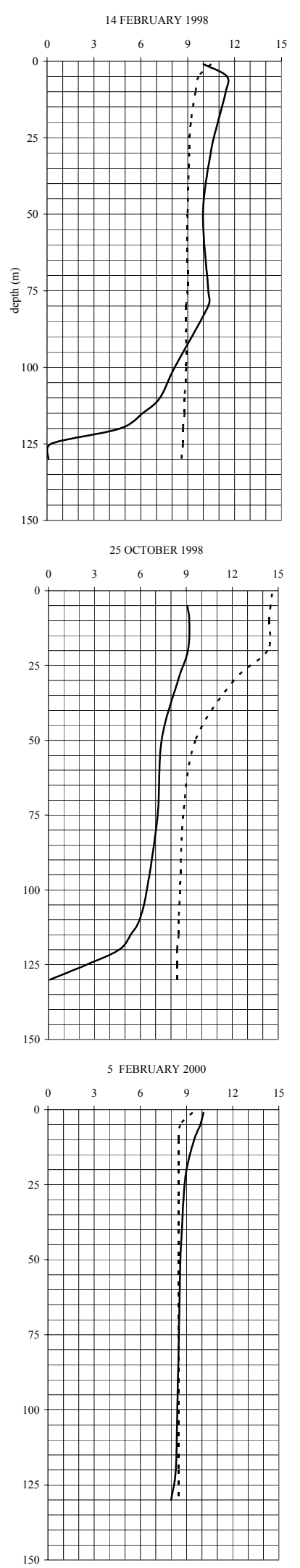

17 MARCH 1998
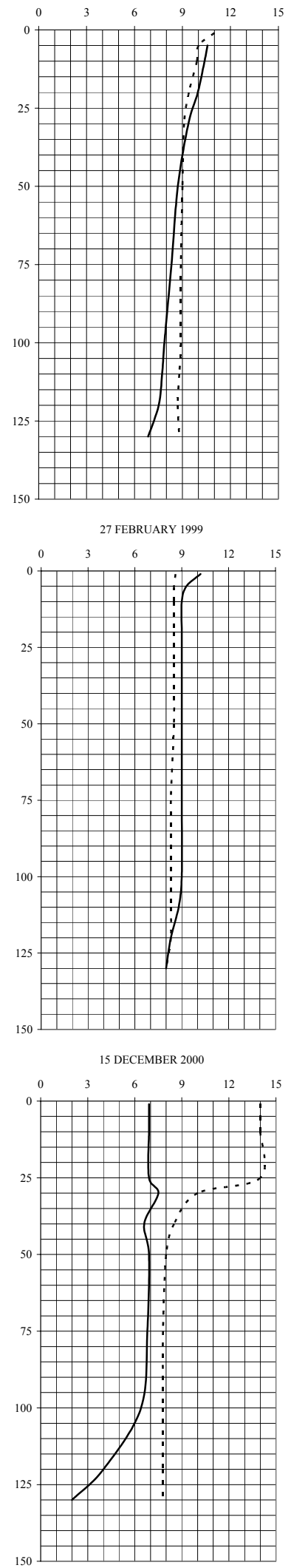

20 APRIL 1998
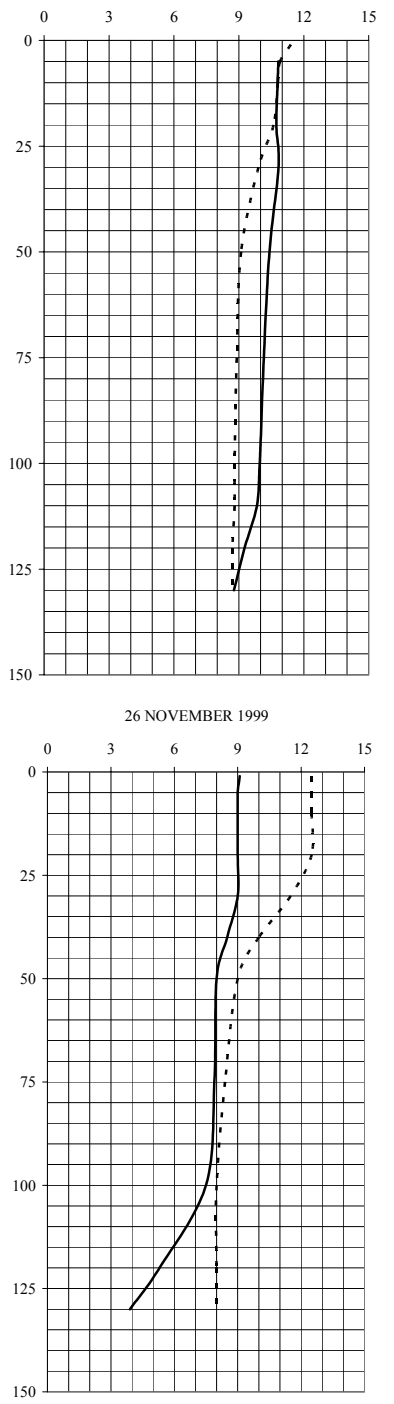

Fig. 5. Vertical profiles of temperature $\left({ }^{\circ} \mathrm{C}\right.$, broken line) and oxygen $\left(\mathrm{mg} \mathrm{l}^{-1}\right.$, full line) at selected dates in Lake Bolsena. 


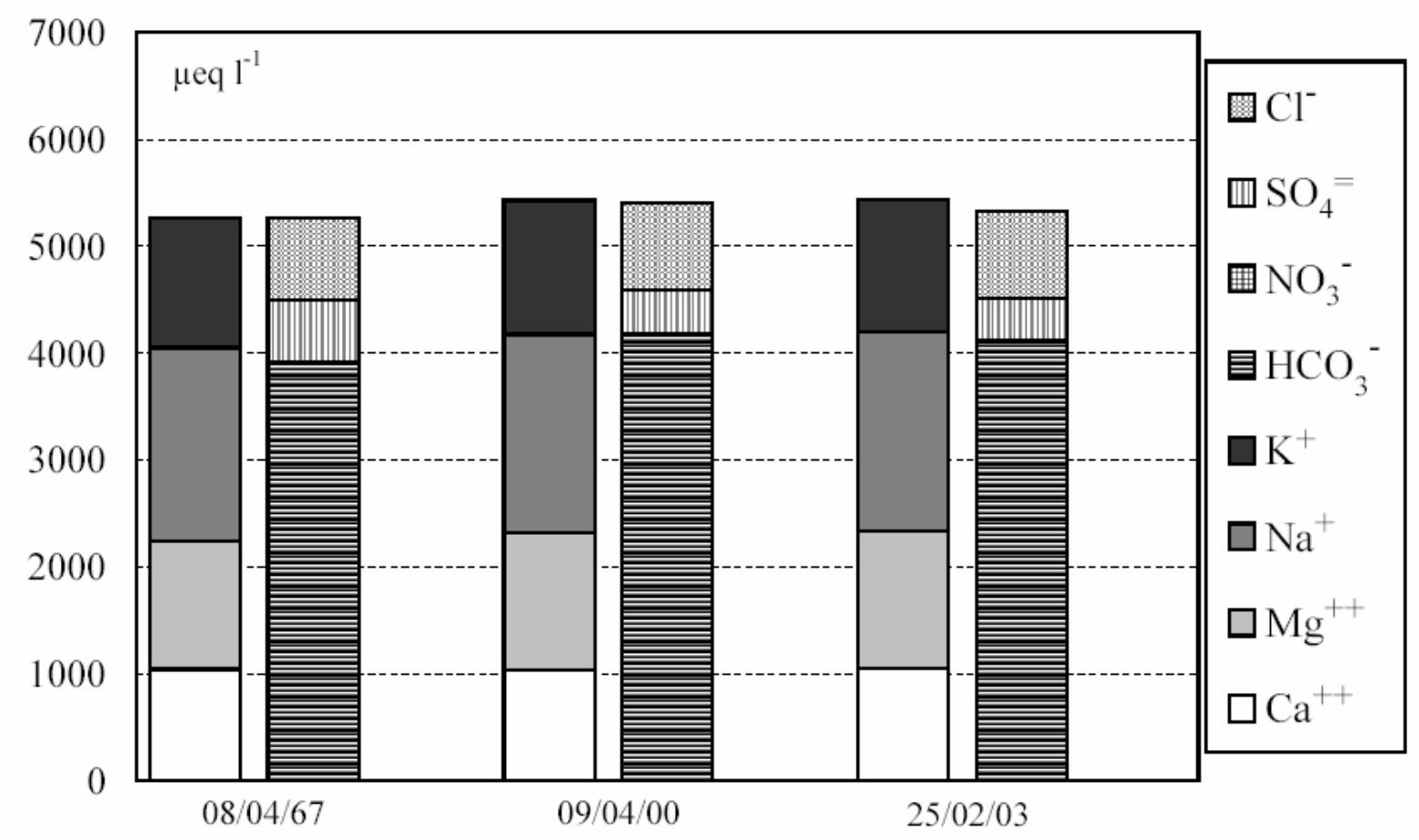

Fig. 6. Comparison of recent and 60s ion concentrations of Lake Bolsena.

In the case of the summer temperature, the increase in the same period was even higher, reaching $34 \%$. As a consequence, thermal stability, defined as the need to homogenise the thermally stratified lake to homothermy in adiabatic conditions, increased from $151 \mathrm{~J} \mathrm{~m}^{-2}$ to $589 \mathrm{~J} \mathrm{~m}^{-2}$.

A further worrying variation from the $60 \mathrm{~s}$ has become apparent for the hydrology of the lake. Due to the tapping of underground water for irrigation and domestic use the extraction of water increased from around 5 to $3010^{6} \mathrm{~m}^{3} \mathrm{y}^{-1}$ during the period 1960-2000 (Pagano et al. 1998; Dragoni 1998). There has also been a slight decrease in the quantity of precipitation over the last four decades (Fig. 7), while the air temperature has increased by about one degree Celsius over approximately the last hundred years (Dragoni \& Gnucci 2002). As a consequence, the outflow discharge has decreased from about 100 to $2510^{6} \mathrm{~m}^{3} \mathrm{y}^{-1}$, and the lake level has fallen markedly (Fig. 7). The theoretical water renewal time has therefore increased from about 100 to $400 \mathrm{y}$ (Associazione Lago di Bolsena 2003).

Variations occurring in the thermal stability of the water and hydrology, considered together with the considerable maximum depth of the lake, suggest that there may be warming potential for the establishment of meromictic conditions. However, this scenario appears very unlikely, due to the large surface area of the lake, the absence of surrounding mountains, and the high winds of the area. Nevertheless, the relevant variations occurring in the lake thermal structure indicate an increasing susceptibility of the lake to eutrophication and to other types of pollution.

\section{CONCLUSIONS}

The area which includes Lake Bolsena and its watershed is exceptionally rich in natural and economic resources, as it is located in one of the most historic parts of Europe with a great deal to offer in terms of high quality tourism. However, the data emerging from this study regarding the quality of the water of the lake and its tributaries highlight the extreme fragility of the area's hydrological system.

Due to the origins of its basin, the catchment of Lake Bolsena is very small compared to both the surface area of the lake and its volume. Also, the hydrogeological basin covers a small area, this means that the lake water chemistry depends to a marked extent on inputs from the atmosphere, as is clear from a comparison between the chemistry of the atmospheric depositions and that of the lake, possibly made more evident in light of the longer theoretical water renewal time. The variables which are mostly dependent on atmospheric inputs are nitrogen, chloride, and sulphate; the in-lake concentrations of nitrogen are however, highly dependent on uptake from catchment and on biological processes in the lake water. In contrast, weathering in the watershed is the dominant process in determining concentrations of bicarbonate, calcium, magnesium, sodium and potassium. The prevalence of volcanic rocks together with the impact of atmospheric deposition gives rise to a characteristic ionic spectrum in which bicarbonate dominates the anions, and $\mathrm{Na}, \mathrm{Mg}$, and $\mathrm{K}$ and $\mathrm{Ca}$, are 

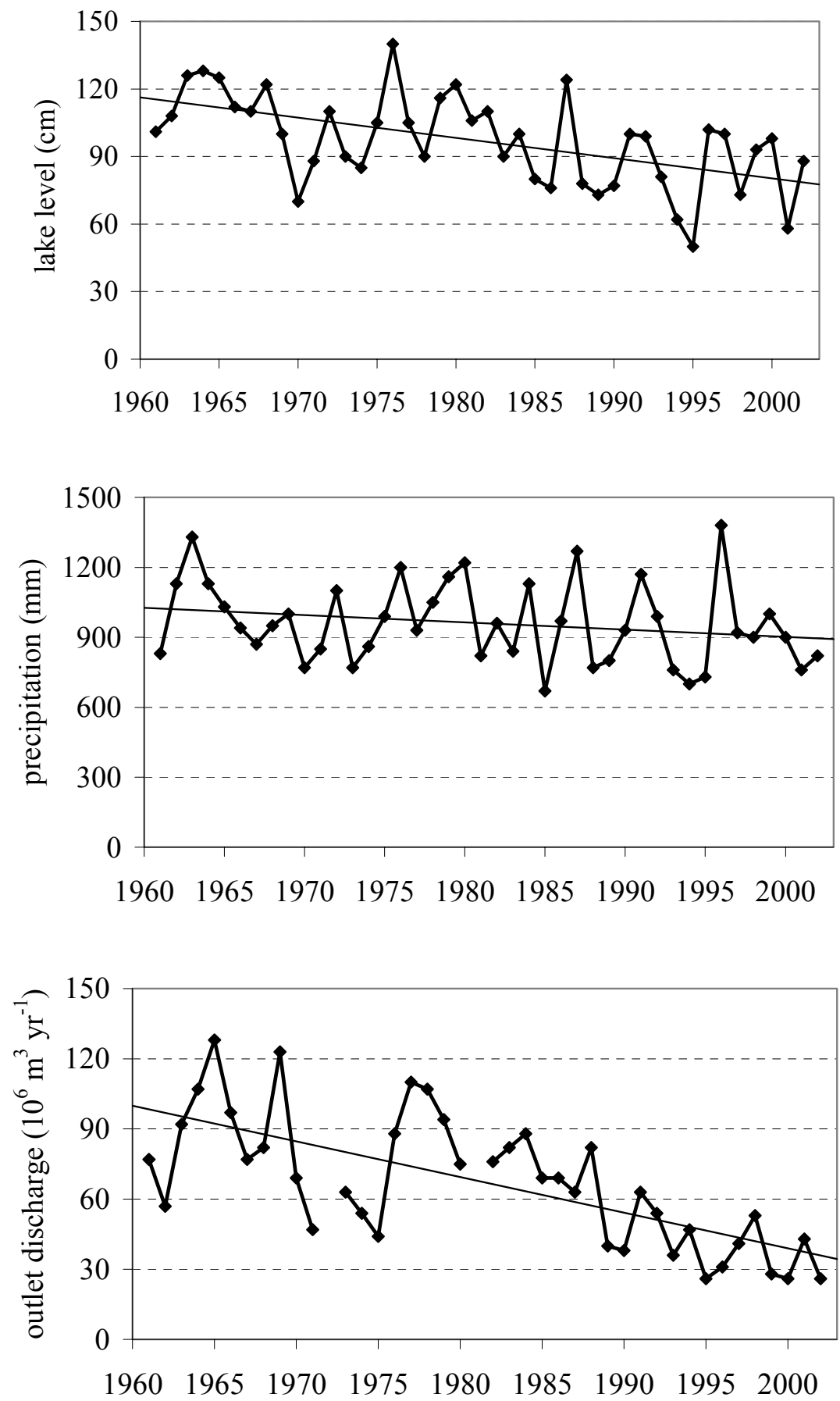

Fig. 7. Annual amount of precipitation in the station of Acquapendente, decrease of the Lake Bolsena outflow discharge and of the water level.

almost equal in importance. This composition is evident in the other four lakes used for comparative purposes, all four of which are fed from watersheds with volcanic rocks.

The present phosphorus concentrations in Lake Bolsena, along with the seasonal oxygen variations, show that the deepest zone of the lake is in a mesotrophic condition. However, due to the large surface area of the lake, more detailed investigations of the shoreline water must be made, as locally different situations, caused by point discharges (illegal or agricultural), cannot be ruled out. The sewage collector around the lake prevents domestic sewage from reaching the lake water, and has indisputably had a crucial role in limiting the eutrophication processes of which the lake was at risk in the 70s and $80 \mathrm{~s}$, when the water quality had deteriorated. Nev- 
ertheless, as the drainage system is mixed, collecting sewage together with run-off water, a portion of the clean water which used to reach the lake is now prevented from doing so. To get round this drawback and enable some of this water to reach the lake, a new drainage system would have to be constructed to separate the clean water from the sewage.

While this study is primarily aimed at investigating the chemistry of the lake, we must also emphasise the necessity for researching hydrological aspects. Due to its natural characteristics, Lake Bolsena had a very long renewal time, and every time water is removed from the lake this situation is aggravated. The use of water for agricultural purposes or for drinking removes precious water from the lake, increasing its susceptibility to eutrophication and lengthening the time required for recovery from episodes of pollution. Additional to this excessive exploitation of the water in the watershed there is also the increasing surface and atmospheric temperatures, which accentuate the phenomenon of evaporation, leading to further destabilisation of the lake ecosystem. Therefore it is necessity for all ongoing or planned economic activities in the watershed to take into account of all the issues connected with the use of water, so as to stop the removal of water from the lake which has been increasing for thirty years and which risks inflicting irreversible damage on the lake water quality.

\section{ACKNOWLEDGMENTS}

We are grateful to Dr. Massimo Guidi (CNR Geosciences and Georesources Institute, Pisa, Italy) for comments on the manuscript.

\section{REFERENCES}

A.P.H.A., A.W.W.A., W.E.F. 1992. Standard Methods for the examination of water and wastewater. Am. Publ. Healt Ass., Washington.

A.P.H.A., A.W.W.A., W.E.F. 1998. Standard Methods for the examination of water and wastewater. (Method $3120 \mathrm{~B})$. Am. Publ. Healt Ass., Washington.

Ambrosetti,W., L. Barbanti \& N. Sala. 2003. Residence time and physical processes in lakes. J. Limnol., 62 (Suppl. 1): $1-15$.

Arnorsson, S.Y \& A. Andresdottir. 1995. Process controlling the distribution of boron and chlorine in natural waters in Iceland. Geochimica et Cosmochimica Acta, 59 (20): 4125-4146.

Associazione Lago di Bolsena. 2003. Il Lago di Bolsena, note ambientali ad uso delle scuole. Bolsena: $64 \mathrm{pp}$.

Barbanti, L \& A. Carollo. 1966. Lago di Bolsena: rilevamento batimetrico e note morfologiche. Mem. Ist. ital. Idrobiol., 20: 133-151.

Camponeschi, B. \& L. Lombardi. 1969. Regione vulcanica dei Monti Sabatini: carta idrogeologica 1:100000. Memorie della Società geologica d'Italia, 8, ndeg.1: 25-55.

Camusso, M., \& S. Polesello. 2000a. Determinazione di anioni (cloruro, nitrato, solfato, bromuro, fluoruro, fosfato e nitrito) mediante cromatografia ionica. Notiziario dei metodi analitici per le acque IRSA-CNR, 2000 (2): 1-7.

Camusso, M., \& S. Polesello. 2000b. Determinazione di cationi (sodio, ammonio, potassio, magnesio e calcio) me- diante cromatografia ionica. Notiziario dei metodi analitici per le acque IRSA-CNR, 2000 (2): 8-13.

Capelli, G., R. Mazza, G. Giordano, A. Cecili, \& R. Salvati. 2000. The colli Albano Volcano (Rome, Italy): breakdown of the equilibrium of a hydrogeological unit as a result of unplanned and uncontrolled over-exploitation. Hydrogéologie, 4: 63-70.

Carollo, A. \& L. Barbanti. 1971. Problemi di limnologia fisica connessi con l'attuazione dello schema di progetto Angelini. In: Istituto Italiano di Idrobiologia (Ed.). Limnologia ed ecologia dei laghi di Bolsena, Bracciano, Trasimeno e Vico: situazione attuale e prevedibili conseguenze derivanti da una loro utilizzazione multipla. Istituto Italiano di Idrobiologia, Verbania Pallanza: 25-111.

Cioni, R., M. Guidi, B. Raco, L. Marini, B. Gambardella. 2003. Water chemistry of Lake Albano (Italy). J. Volcanol. Geotherm. Res., 120: 179-195.

Dragoni, W. \& L. Gnucci. 2002. Impact of climatic variations on the Bolsena Lake. Proc. Int. Conf. "Residence time in lakes: science, management, education". Bolsena (Viterbo, Italy), September 29-October 32002.

Dragoni, W. 1998. Some considerations on the climatic changes, water resources and water needs in the Italian region south of the $43^{\circ} \mathrm{N}$. In: Issar, A., N. Brown (Eds). Water, Environment and Society in Times of Climatic Change. Kluwer: 241-271.

Fresenius, W., K.E. Quentin \& W. Schneider (Eds). 1988. Water Analysis. Springer-Verlag, Berlin: 804 pp.

Funiciello, R., G. Giordano, D. De Rita, M.L. Carapezza \& F. Barberi. 2002. L'attività recente del cratere del Lago Albano di Castelgandolfo. Rend. Fis. Acc. Lincei, 13: 113-143.

García-Ruiz, R., I. Hernández, J. Jucena \& F.X. Niell. 2000. Significance of phosphomonoesterase activity in the regeneration of phosphorus in a meso-eutrophic, P-limited reservoir. Soil Biology \& Biochemistry, 32: 1953-1964.

Gerletti, M. 1967. Lago di Bolsena: caratteristiche chimiche delle acque pelagiche. Mem. Ist. ital. Idrobiol., 21: 145-164.

Giggenbach, W.F. 1990. Water and gas chemistry of Lake Nyos and ist bearing on the eruptive process. In: F. Le Guern \& G.E. Sigvaldason (Eds). The Lake Nyos event and natural $\mathrm{CO}_{2}$ degassing. II. J. Vulcanol. Geotherm. Res., 42: 337-362.

Golterman, H.L., R.S. Clymo \& M.A.M. Ohnstand. 1978. Methods for physical and chemical analysis of fresh waters. I.B.P. Handbook No. 8, Blackwell, Oxford: 213 pp.

Gran, G. 1952. Determination of the equivalence point in potentiometric titration II. Analyst, 77: 661-671.

Hartley, A.M, W.A. House, M.E. Callow \& B.S.C. Leadbeater. 1995. The role of a green alga in the precipitation of calcite and the coprecipitation of phosphate in freshwater. Int. Rev. ges. Hydrobiol., 80: 385-401.

ISO 11885 1996. Water quality. Determination of 33 elements by inductively coupled plasma atomic emission spectrometry.

Istituto di Ricerca Sulle Acque. 1974. Indagini limnologiche sui laghi di Bolsena, Bracciano, Vico e Trasimeno. Quaderni IRSA, 17: $179 \mathrm{pp}$.

Istituto Italiano di Idrobiologia (Ed.). 1971. Limnologia ed ecologia dei laghi di Bolsena, Bracciano, Trasimeno e Vico: situazione attuale e prevedibili conseguenze derivanti da una loro utilizzazione multipla. Istituto Italiano di Idrobiologia, Verbania Pallanza: 236 pp.

Koschel, R.H. 1997. Structure and function of pelagic calcite precipitation in lake ecosystems. Verh. int. Ver. Limnol., 26: 343-349.

Kurz, P. 2000. Calcium carbonate biomineralisation in freshwater picoplancton. Diploma thesis. EAWAG, Limnological Research Center, Kastanienbaum, Switzerland: 62 pp.

Lami, A., F. Niessen, P. Guilizzoni, J. Masaferro \& C. Belis. 1994. Paleolimnological studies of the eutrophication of volcanic Lake Albano (Central Italy). J. Paleolimnol., 10: 181-197. 
Locardi, E., G. Lombardi, R. Funiciello \& M. Porotto. 1976. The main volcanic Groups of Latium (Italy): relations between structural evolution and petrogenesis. Intern. Colloq. Planet. Geol. Geologica Romana, 15: 279-300.

Manca, M., A. Calderoni and R. Mosello. 1992. Limnological research in Lago Maggiore: studies on hydrochemistry and plankton. Mem. Ist. ital. Idrobiol., 50: 171-200.

Margaritora, G.F. 1992. Limnology in Latium: the volcanic lakes. Mem. Ist. ital. Idrobiol., 50: 319-336.

Martini, M., L. Giannini, F. Prati, F. Tassi, B. Capaccioni, P. Bozzelli. 1994. Chemical characters of crater lakes in the Azores and Italy: the anomaly of Lake Albano. Geochem. J., 28: 173-184.

Martini, P. 1985. The project CO.B.I.S. plants. Proc. Int. Congr. "Lakes Pollution and Recovery", Rome, April 1518, 1985: 188-193.

Masaferro, J. 1994. Paleolimnologia di sei laghi vulcanici e di un lago argentino di origine glaciale. Università degli Studi di Parma. Tesi di Dottorato: $198 \mathrm{pp}$.

Mosello, R., M.C. Brizzio, D. Kotzias, A Marchetto, D. Rembges \& G. Tartari. 2002. The chemistry of atmospheric deposition in Italy in the framework of the National Integrated Programme for the Control of Forest Ecosystems (CON.ECO.FOR.). In: Mosello, R., B. Petriccione \& A. Marchetto (Eds). Long-term ecological research in Italian forest ecosystems. J. Limnol., 61 (Suppl. 1): 77-92.

Nappi, G., A. Renzulli \& P. Santi. 1991. Evidence of incremental growth in the Vulsinian calderas (Central Italy). $J$. Volcan. Geotherm. Res., 47: 13-31.

Niessen, F., A. Lami \& P. Guilizzoni. 1993. Climatic and tectonic effects on sedimentation in central Italian volcano lakes (Latium) - Implications from high resolution seismic profiles. In: Negendank, J.F.W. \& B. Zolitschka (Eds). Lecture notes in Earth Science, 49: 129-148.

Pagano, G. 1998. Studio idrogeologico del bacino di Bolsena. Assessorato Ambiente. Provincia di Viterbo.

Pagnotta, R. \& E. Rolle. 1982. Caratteristiche attuali e possibile evoluzione della qualità delle acque del Lago di Bolsena. Ingegneria Sanitaria, 30: 145-151.

Pagnotta, R., T. La Noce, M. Pettine \& A. Puddu. 1987. I laghi dell'Italia centrale: classificazione trofica ed analisi dei fattori che la influenzano. Atti A.I.O.L., 7: 385-396.

Parello, F., W. D'Alessandro, A. Aiuppa \& C. Federico. 2001. Cartografia geochimica degli acquiferi Etnei. Gruppo Nazionale per la Difesa delle Catastrofi Geologiche del C.N.R., Pubbl. n. 2190: 102 pp.

Pichler, H. 1970. Italienische Vulkan-Gebiete. I: Somma-Vesuv., Latium, Toscana. In: Lotze, F. (Ed). Sammlung

Received: August 2003

Accepted: January 2004
Geologischer Führer, 51, Gebr. Bornträger Vrl., Berlin: $258 \mathrm{pp}$.

Rabalais, N.N. 2002. Nitrogen in aquatic ecosystems. Ambio, 31: $102-112$.

Riebesell, U., D.A. Wolf-Gladrow \& V. Smetacek. 1993. carbon dioxide limitation of marine phytoplankton growth rates. Nature, 361: 249-251.

Sigurdsson, H., J.D. Devine, F.M. Tchoua, T.S. Presser, M.K.W. Pringle, \& W.C. Evans. 1987. Origin of the lethal gas burst from Lake Monoun, Cameroun. J. Vulcanol. Geotherm. Res., 31: 1-16.

Stumm, W. \& J. Morgan. 1981. Aquatic chemistry. Wiley Interscience, New York: $780 \mathrm{pp}$.

Tartari, G. \& M. Camusso. 1988. Boron content in freshwaters of northern Italy. Water, Air, Soil Pollut., 38 : 409-417.

Tartari, G.A. \& R. Mosello. 1997. Metodologie analitiche e controlli di qualità nel laboratorio chimico dell'Istituto Italiano di Idrobiologia del Consiglio Nazionale delle Ricerche. Documenta Ist. ital. Idrobiol., 60: 160 pp.

Thompson, J.B., S. Schultze-Lam, T.J. Beveridge \& D.J. Des Marais. 1997. Whiting events: biogenic origin due to the photosynthetic activity of cyanobacterial picoplankton. Limnol. Oceanogr., 42: 133-141.

U.S. E.P.A. 1986. Dissolved sodium, ammonium, potassium, magnesium and calcium in wet deposition by chemical suppressed ion chromatography. Method 300.7. Cincinnati, Ohio.

U.S. E.P.A. 1994. Determination of metal and trace elements in water and wastes by inductively coupled plasma atomic emission spectrometry. Method 200.7. U.S.E.P.A., Environmental Monitoring and Support Laboratory, Cincinnati, Ohio.

U.S. E.P.A. 1996. SW-846. Inductively coupled plasma atomic emission spectrometry. Method 6010B. U.S.E.P.A., Environmental Monitoring and Support Laboratory, Cincinnati, Ohio.

Valderrama, J.C. 1977. Methods used by the Hydrographic Department of the National Board of Fisheries. Goteborg, Sweden.

Valderrama, J.C. 1981. The simultaneous analysis of total nitrogen and total phosphorus in natural waters. Marine Chemistry, 10: 109-122.

Vollenweider, R.A. 1975. Input-output models with special reference to phosphorus loading concept in limnology. Schweiz. Z. Hydrol., 37: 53.

Westcott, C.C. 1978. pH measurements. Academic Press, New York: $172 \mathrm{pp}$. 